\title{
Transcriptional Repressor CTCFL
}

National Cancer Institute

\section{Source}

National Cancer Institute. Transcriptional Repressor CT CFL. NCI Thesaurus. Code

C111823.

Transcriptional repressor CT CFL (663 aa, 76 kDa) is encoded by the human CT CFL gene.

This protein plays a role in gene regulation through transcriptional repression. 